\title{
FAKTOR-FAKTOR YANG MEMPENGARUHI SUBTIPE GEJALA MOTORIK PENYAKIT PARKINSON
}

\author{
Attiya Istarini ${ }^{1}$, Yuliarni Syafrita ${ }^{2}$, Restu Susanti ${ }^{3}$ \\ 1PPDS Neurologi FK UNAND, Jalan Perintis Kemerdekaan No.14D, Padang \\ Email: dr.attiyaistarini@gmail.com \\ ${ }^{2}$ Staff Bagian Neurologi FK UNAND, Jalan Perintis Kemerdekaan No.14D, Padang \\ Email: ysyafrita@yahoo.com \\ ${ }^{3}$ Staff Bagian Neurologi FK UNAND, Jalan Perintis Kemerdekaan No.14D, Padang \\ Email: restususanti@yahoo.com
}

Submitted : 11-02-2020,Reviewer:20-02-2020, Accepted: 21-02-2020

\begin{abstract}
ABSTRAK
Latar Belakang: Penyakit Parkinson (PD) adalah penyakit neurodegeneratif kronik yang bermanifestasi sebagai gangguan gerak. Berdasarkan gejala motorik, PD diklasifikasikan menjadi subtipe tremor dan subtipe instabilitas postural dan gangguan berjalan (PIGD). Subtipe gejala motorik merupakan prediktor progresivitas penyakit, respon terapi, dan kualitas hidup pasien Parkinson. Tujuan penelitian ini mencari faktor- faktor yang mempengaruhi subtipe gejala motorik penyakit Parkinson.

Metode: Penelitian ini menggunakan desain cross sectional. Sampel dipilih dengan metode consecutive sampling yang memenuhi kriteria inklusi dan ekslusi. Subjek penelitian sebanyak 58 orang. Analisa statistik menggunakan SPSS. Nilai $\mathrm{p}<0.05$ dianggap bermakna secara statistik.

Hasil: Dari 58 pasien, 55.2\% laki-laki dengan rerata usia 63.5 \pm 8.5 tahun. Rerata usia saat onset 57.9 \pm 9.5 tahun dan durasi penyakit $6.1 \pm 4.6$ tahun. Gejala motorik $53.4 \%$ dominan tremor. Terdapat hubungan yang bermakna stadium penyakit dengan subtipe gejala motorik $(p<0.001)$. Tidak terdapat hubungan usia pasien, usia saat onset dan durasi penyakit dengan subtipe gejala motorik.

Kesimpulan: Terdapat hubungan stadium penyakit dengan subtipe gejala motorik. Usia pasien, usia saat onset dan durasi penyakit tidak berpengaruh pada gejala motorik pasien Parkinson.
\end{abstract}

Kata kunci: Penyakit Parkinson, stadium penyakit Hoehn dan Yahr, tremor, PIGD

\begin{abstract}
Background: Parkinson's disease (PD) is a chronic neurodegenerative disease that manifests as movement disorders. Based on motor symptoms, $P D$ is classified into subtypes of tremor and postural instability gait disorders (PIGD). The motor symptoms subtype is a predictor of disease progression, therapeutic response, and quality of life for Parkinson's patients. The purpose of this study is to identify some factors that influence motor symptoms in Parkinson's disease.

Methods: This research use cross sectional design. Samples were selected by consecutive sampling method that met the inclusion and exclusion criteria. Research subjects were 58 people. Statistical analysis using SPSS. $p$ values $<0.05$ were considered statistically significant.

Results: This research include 58 patients, $55.2 \%$ were men with range of age $63.5 \pm 8.5$ years old. The mean age at onset was $57.9 \pm 9.5$ years and duration of disease $6.1 \pm 4.6$ years. Motor symp toms $53.4 \%$ dominant tremor. There was a significant relationship between disease stage and motor symptom subtypes $(p<0.001)$. There is no relationship between the patient's age, age at onset and duration of the disease with motor symptom subtypes.

Conclusions: There is a relationship between disease stage and motor symptom. The patient's age, age at onset and duration of the disease are not related to the motor symptoms of Parkinson's patients.
\end{abstract}

Keywords: Parkinson's disease, Hoehn and Yahr disease staging, tremor, PIGD 


\section{PENDAHULUAN}

Penyakit Parkinson (PD) adalah penyakit neurodegeneratif kronik yang disebabkan hilangnya neuron dopaminergik di Substansia Nigra pars kompakta (SNpc) ganglia basal. Berkurangnya neurotransmitter dopamin bermanifestasi sebagai gangguan gerak diantaranya resting tremor, rigiditas, bradikinesia, dan gangguan postural. Tremor merupakan gejala motorik yang paling awal muncul, kemudian pada stadium lanjut akan muncul bradikinesia, gangguan postural dan keseimbangan. ${ }^{1,2}$

Prevalensi PD semakin meningkat seiring dengan bertambahnya usia, berkembang cepat dan progresif, menyebabkan kematian dan kecacatan. Prevalensi PD secara keseluruhan di dunia berkisar 300 kasus per 100.000 penduduk/tahun dan meningkat lebih dari $3 \%$ pada usia diatas 80 tahun. $^{3}$ Di Indonesia sebagian besar penyakit ini ditemukan pada umur 40-70 tahun, dengan rata-rata pada umur 58-62 tahun dan hanya sekitar 5\% yang terjadi pada umur dibawah 40 tahun. ${ }^{4}$ Di Sumatera Barat belum ada data pasti pasien PD. Berdasarkan data penelitian sebelumnya pada tahun 2014 jumlah pasien Parkinson di kota Padang berkisar 49 orang dengan rata-rata usia $60-70$ tahun. $^{5}$

Jancovic et al, mengklasifikasikan PD menjadi subtipe tremor dan subtipe instabilitas postural dan gangguan berjalan (PIGD). ${ }^{6}$ Klasifikasi ini sangat penting dilakukan karena subtipe gejala motorik berhubungan dengan progresivitas penyakit, respon terapi, prognosis, dan kualitas hidup pasien. ${ }^{7}$ Subtipe tremor berkembang relatif lambat (benign) pada pada onset usia muda, dan memiliki angka survival rate lebih tinggi dibandingkan gejala PIGD. Banyak faktor yang berhubungan dengan manifestasi gejala motorik, diantaranya faktor genetik, usia saat onset, progresivitas penyakit, serta lokasi kerusakan neuron dopaminergik dan deposisi Lewy Bodies. ${ }^{8,9}$ Berdasarkan uraian latar belakang diatas, penulis tertarik meneliti lebih lanjut mengenai beberapa faktor yang berhubungan dengan subtipe gejala motorik penyakit Parkinson.

\section{METODE PENELITIAN}

Penelitian ini menggunakan desain cross-sectional dengan pendekatan deskriptif komparatif. Populasi adalah penyakit Parkinson yang berobat ke poliklinik Rumah Sakit Umum di kota padang pada tahun 2019. Sampel diambil dengan metode consecutive sampling yang memenuhi kriteri inklusi dan ekslusi. Kriteria inklusi adalah pasien Parkinson yang terdiagnosa secara klinis berdasarkan kriteria Hughes. Gejala parkinsonism dengan riwayat gangguan vaskuler otak, trauma kepala dan tumor intrakranial dieksklusikan dari penelitian ini. Sebanyak 58 orang menjadi subjek penelitian. Pada tahap awal dilakukan pencatatan data karakteristik demografi dan klinis subjek seperti umur, jenis kelamin, usia saat onset, durasi penyakit, dan stadium penyakit berdasarkan kriteria Hoehn dan Yahr (HY). Subtipe gejala motorik diklasifikasikan menjadi dominan tremor dan dominan PIGD berdasarkan rasio skor tremor/PIGD dari Movement Disorder Society Unified Parkinson's Disease Rating Scale (MDS-UPDRS). ${ }^{10}$ Jika rasio yang dihasilkan adalah $\geq 1.15$ maka pasien diklasifikasikan dominan tremor sedangkan jika rasio $\leq 0.90$, maka pasien diklasifikasikan PIGD. Analisa statistik dilakukan secara komputerisasi dengan perangkat lunak SPSS 22.0 untuk windows. Variabel kontinu disajikan sebagai mean \pm standard deviation (SD) dan analisa hubungan antar variabel dilakukan dengan uji $\mathrm{T}$ tidak berpasangan dan uji Mann-Whitney U. Nilai $p<0.05$ dianggap bermakna secara statistik.

\section{HASIL DAN PEMBAHASAN}

Penelitian dilakukan terhadap 58 orang pasien Parkinson yang berobat ke poliklinik Rumah Sakit Umum di kota Padang. Dalam penelitian ini 55.2\% pasien adalah laki-laki dengan rerata usia $63.5 \pm$ 
8.5 tahun. Rerata usia saat onset $57.9 \pm 9.5$ tahun dan durasi penyakit $6.1 \pm 4.6$ tahun. Berdasarkan gejala motorik, subtipe tremor sebanyak $53.4 \%$ dan PIGD sebanyak $46.6 \%$. Gambaran karakteristik dasar pasien Parkinson di kota Padang disajikan pada Tabel 1.

Analisis bivariat dilakukan untuk mencari faktor yang mempengaruhi subtipe gejala motorik. Pada penelitian ini terdapat perbedaan yang bermakna stadium penyakit antara kelompok dominan tremor dan PIGD $(\mathrm{p}<0.001)$. Namun, tidak terdapat perbedaan usia pasien, usia saat onset dan durasi penyakit pada kedua kelompok. Hubungan antar variabel disajikan pada Tabel 2.

Tabel 1. Karakteris tik Dasar

\begin{tabular}{lc}
\hline \multicolumn{1}{c}{ Karakte ristik Dasar } & Pasien $(\mathbf{n}=\mathbf{5 8})$ \\
\hline Usia & $63.5 \pm 8.5$ \\
Usia saat onset & $57.9 \pm 9.5$ \\
Jenis kelamin (n, \%) & \\
$\quad$ Laki-laki & $32(55.2)$ \\
$\quad$ Perempuan & $26(44.8)$ \\
Durasi penyakit & $6.1 \pm 4.6$ \\
Stadium penyakit (HY) & $2.7 \pm 1.0$ \\
Subtipe gejala motorik (n, \%) & \\
$\quad$ Dominan tremor & $31(53.4)$ \\
$\quad$ Dominan PIGD & $27(46.6)$ \\
\hline
\end{tabular}

Tabel 2. Hubungan faktor-faktor yang mempengaruhi subtipe ge jala motorik

\begin{tabular}{lccc}
\hline Faktor yang mempengaruhi & \multicolumn{2}{c}{ Subtipe ge jala motorik } & \multirow{2}{*}{ p value } \\
\cline { 1 - 3 } & $\begin{array}{c}\text { Dominan Tremor } \\
\mathbf{n = 3 1}\end{array}$ & $\begin{array}{c}\text { Dominan PIGD } \\
\mathbf{n = 2 7}\end{array}$ & \\
\cline { 2 - 3 } & $62.4 \pm 8.0$ & $64.7 \pm 8.9$ & 0.3 \\
Usia & $57.8 \pm 8.2$ & $57.9 \pm 10.9$ & 0.9 \\
Usia saat onset & $5.4 \pm 4.6$ & $6.8 \pm 4.6$ & 0.2 \\
Durasi Penyakit & $2.0 \pm 0.7$ & $3.3 \pm 0.9$ & $<0.001$ \\
Stadium Penyakit (HY) & &
\end{tabular}

Klasifikasi gejala motorik telah banyak digunakan dalam praktek klinis dan merupakan prediktor progresivitas penyakit PD. Berdasarkan gejala motorik, penyakit Parkinson diklasifikasikan menjadi dominan tremor dan dominan gangguan postural (PIGD). Klasifikasi ini diperoleh dari rasio skor tremor/PIGD MDS-UPDRS. ${ }^{10}$ Subtipe tremor berkembang relatif lambat (benign) dan muncul pada onset usia dibawah 40 tahun. Sedangkan PIGD lebih sering terjadi pada usia diatas 60 tahun, progresivitas penyakit cepat dan memiliki prognosis yang buruk. 7,11 Pada penelitian ini didapatkan lebih dari $50 \%$ pasien berjenis kelamin laki-laki, rata-rata usia saat onset diatas 50 tahun dengan gejala dominan tremor. Tidak terdapat hubungan antara usia saat onset dengan subtipe gejala motorik.

Stadium Hoehn dan Yahr (HY) mengindikasikan progresivitas penyakit PD. Pada tahap awal, gejala motorik yang muncul adalah tremor unilateral. Seiring perjalanan penyakit bradikinesia dan gangguan postural muncul lebih 
dominan. ${ }^{1,2}$ Sebuah penelitian prospektif menunjukkan bahwa setelah 2 tahun diagnosis, gejala gangguan postural dapat terlihat pada $34 \%$ pasien Parkinson dengan stadium HY III. ${ }^{12}$ Hal ini sesuai dengan hasil penelitian kami yang menemukan hubungan yang bermakna antara stadium penyakit dengan subtipe gejala tremor dan PIGD ( $2.0 \pm 0.7$ vs $3.3 \pm 0.9, \mathrm{p}<0.001)$.

Pasien yang baru terdiagnosis PD dalam beberapa tahun terkadang berada pada stadium lanjut dibandingkan pasien yang telah lama menderita PD. Hal ini dikarenakan diawal perjalanan penyakit gejala tremor sering tidak disadari oleh pasien, hingga muncul bradikinesia dan gangguan postural yang mengganggu aktivitas pasien. ${ }^{13}$ Dalam penelitian ini tidak ditemukan hubungan yang bermakna antara durasi penyakit dengan subtipe gejala motorik. Banyak faktor lain yang mempengaruhi manifestasi gangguan gerak diantaranya lokasi dan jumlah kerusakan neuron dopaminergik, deposisi agregat protein abnormal, faktor genetik dan lingkungan. ${ }^{9,14,15}$

Keterbatasan penelitian ini adalah jumlah sampel yang kecil dengan desain penelitian cross sectional. Sebaiknya dilakukan penelitian dengan jumlah sampel yang lebih besar, dengan desain kohort serta identifikasi faktor-faktor lain yang mempengaruhi subtipe gejala motorik seperti faktor genetik, deposisi Lewy Bodies, dan faktor lingkungan.

\section{SIMPULAN}

Penelitian ini menemukan hubungan yang bermakna antara stadium penyakit dengan subtipe gejala motorik PD. Tidak ditemukan hubungan usia pasien, usia saat onset dan durasi penyakit dengan subtipe gejala motorik. Perlu dicari hubungan faktor-faktor lain yang mempengaruhi subtipe gejala motorik penyakit Parkinson.

\section{DAFTAR PUSTAKA}

1. Zigmond MJ, Robert B. Pathophysiology Of Parkinson's Disease dalam Neuropsycho- pharmacology: the $5^{\text {th }}$ Generation Of Progress. Philadelphia: Lippincott/Williams \& Wilkins. 2002: 1781-1789.

2. Fahn S, Jankovic, J. Parkinsonisme: Clinical feature and differential diagnosis dalam Principles and practice of movement disorders. Philadelphia: Churchill Livingstone /Elsevier.2007:79-95

3.

oewe W, Tanner C, Halliday G, Brundin P, Volkmann J, Schrag A, Lang A. Parkinson disease. Nature Reviews Disease Primers. 2017(3): 17013.

4. Kelompok Studi Gangguan Gerak PERDOSSI. Buku panduan tatalaksana penyakit Parkinson dan gangguan gerak lainnya. Jakarta. 2015:7-18

5 .

utia D. Hubungan kadar Alfa Sinuklein plasma dengan penyakit Parkinson. Bagian Neurologi FK UNAND. 2014: 68

6.

ankovic J, McDermott M, Carter J, Gauthier S, Goetz C, Golbe L, et al. Variable expression of Parkinson's disease: A base-line analysis of the DATATOP cohort. Neurology. $1990.40(10)$ : 1529-1529.

7.

uyeung M, Tsoi T, Mok V, Cheung C, Lee C, Li R, Yeung E. Ten year survival and outcomes in a prospective cohort of new onset Chinese Parkinson's disease patients. Journal of Neurology, Neurosurgery \& Psychiatry. 2012. 83(6): 607-611.

8.

ellinger K. Neuropathology of Parkinson's

Diseases. Inflammation in Parkinson's Disease. 2014: 25-74. 
9.

henganatt M, Jankovic J. Parkinson

Disease

Subtypes. JAMA

Neurology. 2014.71(4):499.

10.

tebbins G, Goetz C, Burn D, Jankovic J, Khoo T, Tilley B. How to identify tremor dominant and postural instability/gait difficulty groups with the Movement Disorder Society Unified Parkinson's Disease Rating Scale: Comparison with the Unified Parkinson's Disease Rating Scale. Movement Disorders. 2013.28(5):668-670.

11.

ao Z, Shao Y, Han X. Freezing of gait is associated with cognitive impairment in patients with Parkinson disease. Neuroscience Letters. 2017(656): 126-130.

12.

ely, MA, Morris JG, Rail D. The Sydney Multicentre Study of Parkinson's disease: a report on the first 3 years. J Neurol Neurosurg Psychiatry. 1989(3):324-8.

13.

im S, Allen N, Canning C, Fung V. Postural Instability in Patients with Parkinson's Disease. CNS Drugs. 2012. 27(2): 97-112.

14.

ealy DG, Falchi M, O'Sullivan SS.

Phenotype, genotype, and worldwide genetic penetrance of LRRK2-associated Parkinson's disease: a case-control study. Lancet Neurol. 2008(7):583-590.

15. Tanner CM, Ross GW, Jewell SA. Occupation and risk of parkinsonism: a multicenter casecontrol study. Arch Neurol. 2009(66):1106-1113 